\title{
ANALISA STABILITAS DINDING PENAHAN TANAH (RETAINING WALL) AKIBAT BEBAN DINAMIS DENGAN SIMULASI NUMERIK
}

\author{
Oscar Fithrah Nur ${ }^{1}$, Abdul Hakam ${ }^{2}$
}

\begin{abstract}
ABSTRAK
Penggunaan simulasi numerik dalam menganalisa beban dinamis pada struktur dinding penahan tanah diperkenalkan disini. Analisa yang dilakukan didasarkan pada rumusan konvensional dan simulasi dengan menggunakan software komputer. Dinding penahan tanah diberikan perpindahan dan frekuensi getaran, sebagai simulasi dari beban dinamis di lapangan. Pada tahap awal, dihitung stabilitas dinding penahan tanah (retaining wall) dalam kondisi statis dengan menggunakan metode perhitungan stabilitas dinding penahan tanah yang biasa digunakan. Dinding penahan tanah dapat dikatakan stabil, apabila angka keamanan yang diperoleh di atas batas yang diambil. Selanjutnya dilakukan simulasi dengan menggunakan program PLAXIS. Dari simulasi ini diperoleh grafik perpindahan terhadap waktu, kecepatan terhadap waktu dan percepatan terhadap waktu. Kemudian perhitungan dilanjutkan dengan menganalisa stabilitas dinamis dinding penahan dengan dua variasi sudut keruntuhan, yaitu $\alpha=45+\phi / 2$ dan $\alpha=\phi$. Terakhir analisa dilakukan dengan menggunakan metode Mononobe-Okabe untuk mengetahui stabilitas dinamis dinding penahan.
\end{abstract}

Kata Kunci : Dinamika tanah, dinding penahan tanah, stabilitas dinamis.

\section{PENDAHULUAN}

\subsection{Latar Belakang}

Gempa merupakan salah satu peristiwa alam yang sudah dikenal orang. Gempa terjadi sebagai akibat dari pelepasan energi yang terakumulasi sebelumnya untuk jangka waktu tertentu. Bila massa batuan/ tanah pada struktur di kulit bumi tidak sanggup lagi menahan akumulasi energi di dalam bumi, maka massa batuan/ tanah pada struktur tersebut akan meledak yang kemudian menyebarkan getaran dan gelombang ke segala arah sampai tercipta suatu keseimbangan baru. Kerusakan struktur tanah sebagai akibat langsung dari beban gempa adalah seperti menurunnya daya dukung tanah di bawah pondasi, keruntuhan pada dinding penahan tanah dan keruntuhan pada abutmen jembatan. Sedangkan akibat tidak langsungnya adalah seperti kerusakan bangunan akibat getaran yang ditransmisikan dari tanah ke struktur. Oleh karena itu, struktur perlu direncanakan dan dianalisis terhadap gempa yang mungkin terjadi di masa yang akan datang.

Kondisi di atas sama halnya dengan beban dinamis pada struktur yang berasal dari getaran mesin yang sedang beroperasi. Getaran yang dihasilkan mesin tersebut bisa merusak struktur, bahkan dapat membahayakan jiwa manusia. Agar hal ini tidak terjadi, maka kita perlu mengetahui stabilitas dari struktur tersebut untuk menahan beban dinamis yang bekerja padanya.

\footnotetext{
${ }^{1}$ Staf Pengajar Jurusan Teknik Sipil Fakultas Teknik Universitas Andalas, e-mail: oscar@ft.unand.ac.id

${ }^{2}$ Staf Pengajar Jurusan Teknik Sipil Fakultas Teknik Universitas Andalas, e-mail: ahakam@ft.unand.ac.id
} 


\subsection{Tujuan Penelitian}

Tujuan penelitian ini adalah untuk mempelajari stabilitas dinamis dari dinding penahan tanah (retaining wall) dengan menggunakan analisa numerik. Manfaat dari penelitian ini adalah untuk mengetahui stabilitas dinamis dari dinding penahan tanah (retaining wall) menurut hasil analisa numerik dan membandingkan dengan hasil metoda empiris.

\subsection{Batasan Masalah}

Batasan masalah dari penelitian ini adalah :

1. Dimensi ditetapkan sesuai dengan permasalahan yang telah diberikan.

2. Pengecekan angka keamanan (safety factor) dari dinding penahan tanah (retaining wall).

3. Memprediksi perpindahan yang terjadi dan menganalisa keruntuhan pada model dinding penahan tanah (retaining wall) akibat beban dinamis.

4. Hasil analisis dibandingkan dengan hasil pengujian di laboratorium dan catatan yang terdapat di referensi.

\section{DASAR TEORI}

\subsection{Dinamika Tanah}

Ketetapan propertis dinamik tanah merupakan hal yang tidak mudah dalam meyelesaikan permasalahan-permasalahan gempa di bidang geoteknik. Ada banyak cara yang mungkin dilakukan di lapangan dan di laboratorium untuk menentukan propertis dinamik tanah, dimana masingmasingnya memiliki kelebihan dan keterbatasan untuk masalah yang lebih spesifik lagi. Sejumlah parameter disain pergerakan diwajibkan dalam tahap konseptual proyek skala besar untuk disain pondasi dan estimasi biaya yang diperlukan.

Propertis tanah yang mempengaruhi penjalaran gelombang dan kejadian lainnya adalah kekakuan, peredam, angka Poisson dan berat jenis. Dalam hal ini, kekakuan dan peredam sangat penting dan perlu dilakukan evaluasi dalam permasalahan gempa secara geoteknik.

\subsubsection{Karakteristik Umum Geoteknik}

Untuk melakukan analisa gerakan pada pondasi dan kasus gempa dalam teknik sipil diperlukan karakteristik dari propertis dinamika tanah. Dalam menganalisis beban dinamik pada struktur bangunan juga diperlukan ilmu tentang respon sistem struktur tanah terhadap beban dinamik, yang dikenal dengan propertis dinamika tanah.

Respon tanah terhadap beban yang bergerak sangat dipengaruhi oleh propertis mekaniknya. Propertis mekanik yang diperlukan dalam mempelajari penjalaran gelombang, adalah modulus geser $(G)$, rasio redaman $(\lambda)$, dan rasio Poisson (v). Propertis mekanik jenis ini disebut dengan "propertis dinamika tanah", walaupun juga digunakan dalam banyak kasus yang bukan dinamik.

\subsubsection{Modulus Geser dan Redaman}

Propertis dinamik tanah juga memerlukan sebuah sumber energi aktif untuk meningkatkan massa tanah dan atau mempengaruhi gelombang terukur. Percobaan geophysical menyebarkan gelombang seismik pada tanah dengan tegangan rendah (dibawah $10^{-3} \%$ ), sehingga memungkinkan satuan tegangan secara sederhana. Tegangan rendah ini mengikuti teori elastis untuk menyamakan satuan dengan propertis mekanik. Pada tingkat tegangan menengah $\left(\sim 10^{-2} \%\right)$ responnya menjadi non-

\section{2 | J URNAL REKAYASA SIPIL}


linier, untuk tingkat tegangan tinggi $\left(\sim 10^{-1} \%-5 \%\right)$ perilaku dinamik tanah sisa non-linier dan akan mulai mengalami perpindahan permanen (plastis) dan segera mencapai kondisi tidak stabil. Untuk menggambarkan perilaku tegangan beban keseluruhan pada tanah diperlukan pengembangan in-situ dan percobaan laboratorium secara spesifik direncanakan (didisain) sesuai dengan tingkatan tegangan yang mempengaruhi setiap bagian material.

Grafik penurunan modulus geser biasanya ditunjukkan oleh modulus geser normal $G / G_{\max }$. Pada saat tanah kehilangan kekakuan dengan amplitudo tegangan, kemampuannya untuk meredam gaya dinamik menurun. Hubungan antara tegangan geser dan redaman adalah hubungan invers dengan kurva $G / G_{\max }$. Redaman lebih sering disebut rasio redaman $(\lambda)$.

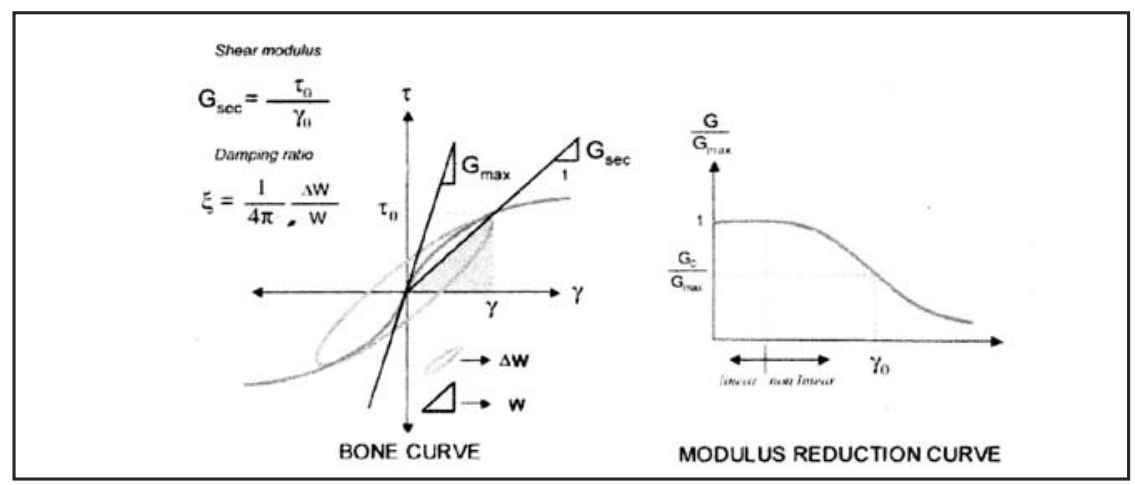

Gambar 1. Kurva Modulus Geser

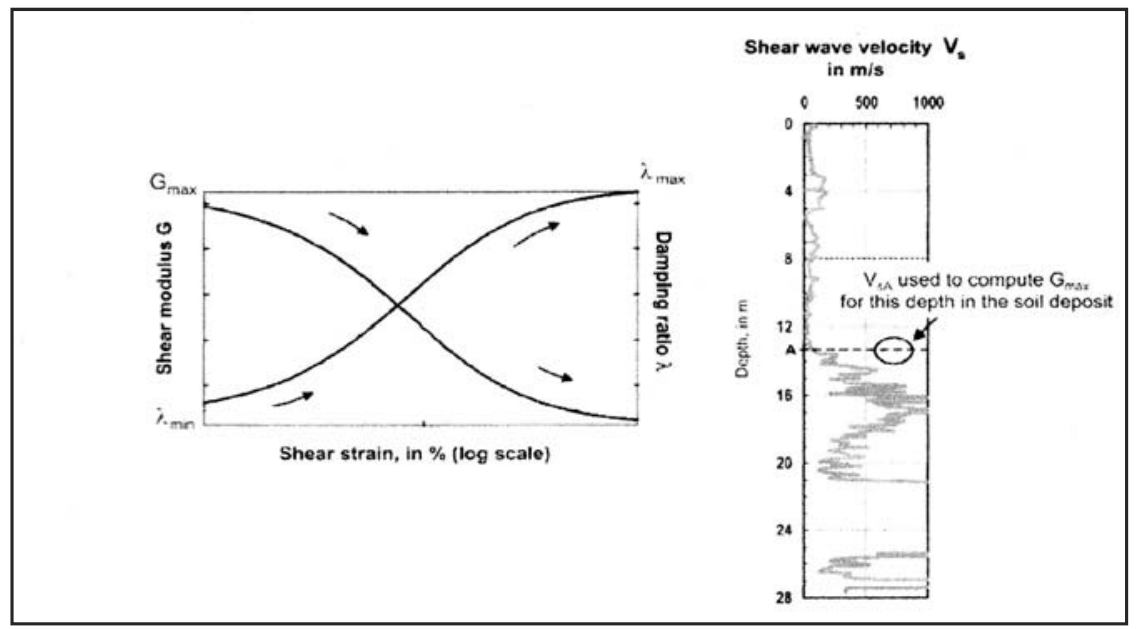

Gambar 2. Kurva Regangan Geser - Modulus Geser

\subsection{Teori Getaran}

\subsubsection{Sistem Satu Derajat Kebebasan (Single Degree of Freedom System)}

Secara umum jumlah derajat kebebasan dari suatu sistem sama dengan variabel bebas yang dibutuhkan untuk menentukan posisi semua bagian sistem pada waktu tertentu.

\subsubsection{Getaran Bebas Tak Teredam}

Gambar 3 menunjukkan sebuah pondasi yang diletakkan pegas dibawahnya. Beban $W$ menunjukkan berat pondasi ditambah dengan beban yang ditahan oleh pondasi tersebut. Bila luas 
permukaan pondasi didefenisikan dengan $A$, maka intensitas penyaluran beban ke tanah dasar dinyatakan dengan :

$$
q=\frac{W}{A}
$$

Akibat dari beban $W$, maka akan terjadi perpindahan $Z s$, dengan persamaan :

$$
Z s=\frac{W}{k}
$$

dimana $k$ adalah konstanta pegas.

Nilai koefisien reaksi tanah dasar $k s$ diperoleh dari persamaan :

$$
k s=\frac{q}{Z s}
$$

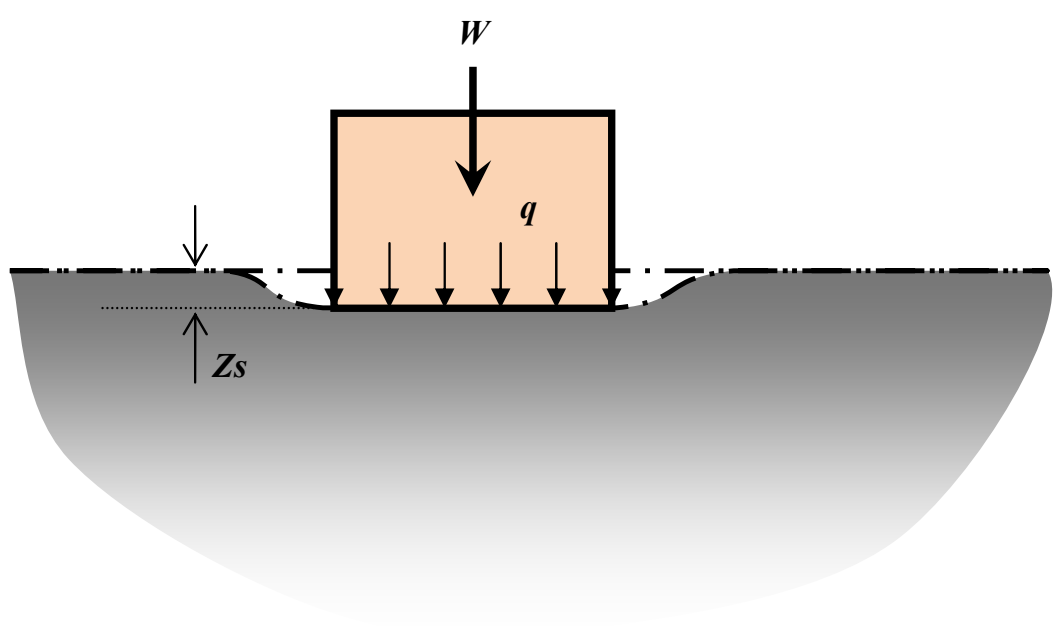

Gambar 3. Getaran Bebas Sistem Massa - Pegas Tanpa Redaman

Jika pondasi dalam posisi setimbang diberi beban, maka sistem akan bergetar. Persamaan gerak dari pondasi yang diberi beban sejauh $z$ didapat dari Hukum II Newton, selanjutnya ditulis :

$$
(W / g) z+k z=0
$$

atau :

$$
z+(k / m) z=0
$$

dimana $g$ adalah percepatan gravitasi, $z=\frac{d^{2} z}{d t^{2}}, t$ adalah waktu dan $m$ adalah massa $(m=W / g)$.

Untuk menyelesaikan persamaan (5) gunakan persamaan berikut

$$
z=A_{1} \cos \left(\omega_{n} t\right)+A_{2} \sin \left(\omega_{n} t\right)
$$

dimana $A_{1}$ dan $A_{2}$ adalah konstanta, $\omega_{n}$ adalah frekuensi sirkular natural tak teredam.

Hasil dari substitusi persamaan (6) ke persamaan (5), diperoleh :

$$
\omega_{n}{ }^{2}\left(A_{1} \cos \omega_{n} t+A_{2} \sin \omega_{n} t\right)+(k / m)\left(A_{1} \cos \omega_{n} t+A_{2} \sin \omega_{n} t\right)=0
$$
atau :

$$
\omega_{n}= \pm \sqrt{\frac{k}{m}}(\mathrm{rad} / \mathrm{dtk})
$$


Dan frekuensi natural tak teredam adalah :

$$
f_{n}=\frac{1}{2 \pi} \sqrt{\frac{k}{m}}(\mathrm{rad} / \mathrm{dtk} \text { atau } \mathrm{Hz})
$$

Frekuensi natural tak teredam dapat digambarkan dalam bentuk lain dengan mensubstitusikan $\mathrm{W} / \mathrm{g}$ untuk $m$ dan $Z s$ untuk $W / k$. Sehingga, diproleh :

$$
f_{n}=\frac{1}{2 \pi} \sqrt{\frac{g}{Z s}} \quad(\mathrm{rad} / \mathrm{dtk} \text { atau } \mathrm{Hz})
$$

Dari hal di atas, dapat dilihat bahwa untuk getaran tak teredam dari sistem satu derajat kebebasan, gerakan yang terjadi adalah gerakan harmonis dengan frekuensi natural $f_{n}$.

Jika perpindahan dan kecepatan pada saat $t=0$ adalah $z_{o}$ dan $z$, selanjutnya diperoleh nilai $A_{1}$ dan $A_{2}$ sebagai berikut :

$$
A_{1}=z_{o} \quad ; \quad A_{2}=z_{o} / \omega_{n}
$$

\subsubsection{Getaran Bebas dengan Redaman}

Bagian matematis yang paling sederhana adalah redaman viscous atau dashpot, seperti pada Gambar 3. Gaya redaman berbanding lurus dengan kecepatan $z$ dan mempunyai nilai yang dapat dihitung dari koefisien redaman viscous $(c)$ dengan satuan $\mathrm{kg} . /(\mathrm{m} / \mathrm{dtk})$ atau $\mathrm{kg} . \mathrm{dtk} / \mathrm{m}$. Redaman mempunyai suatu gaya yang berlawanan gerak terhadap massa.

Untuk sistem getaran bebas pada Gambar 3, persamaan gerak differensial dapat diperoleh dengan menggunakan Hukum II Newton dengan mengukur perpindahan dari posisi diam. Perpindahan positif akan menghasilkan suatu gaya pegas yang beraksi terhadap massa dalam arah negatif.

Penjumlahan dari gaya vertikal akan menghasilkan persamaan :

$$
m z+c z+k z=0
$$

Untuk getaran bebas, dimisalkan $z=A e^{r t}$ disubstitusikan ke persamaan (11), diperoleh :

$$
r^{2}+(c / m) r+(k / m)=0
$$

dimana solusi dari persamaan (12) :

$$
r=-\frac{c}{2 m} \pm \sqrt{\frac{c^{2}}{4 m^{2}}-\frac{k}{m}}
$$

Ada tiga kondisi yang harus dipertimbangkan untuk persamaan (13), yaitu :

1. Jika $c / 2 m>\sqrt{k / m}$, maka nilai akar-akar dari persamaan (12) adalah real dan bernilai positif. Atau dengan kata lain, nilai r pada persamaan (13) adalah real dan bernilai positif. Mengacu pada kasus overdamping.

2. Jika $c / 2 m=\sqrt{k / m}$, maka $r=-c / 2$. Mengacu pada kasus critical damping.

Sehingga untuk kasus ini, nilai redaman $c=c_{c}=2 \sqrt{\mathrm{km}}$

3. Jika $c / 2 m<\sqrt{k / m}$, maka nilai akar-akar dari persamaan (12) menjadi bilangan kompleks, dimana $r=-\frac{c}{2 m} \pm i\left(\sqrt{\frac{k}{m}-\frac{c^{2}}{4 m^{2}}}\right)$. Mengacu pada kasus underdamping.

Selanjutnya rasio redaman $D$ dapat didefenisikan dengan persamaan :

$$
D=c / c_{c}=c / \sqrt{2 k m}
$$


Dengan menambahkan rasio redaman $D$, maka persamaan (13) dapat ditulis menjadi :

$$
r=-\frac{c}{2 m} \pm \sqrt{\frac{c^{2}}{4 m^{2}}-\frac{k}{m}}=\omega_{n}\left(-D \pm \sqrt{D^{2}-1}\right)
$$

$\operatorname{dimana} \omega_{n}=\sqrt{k / m}$

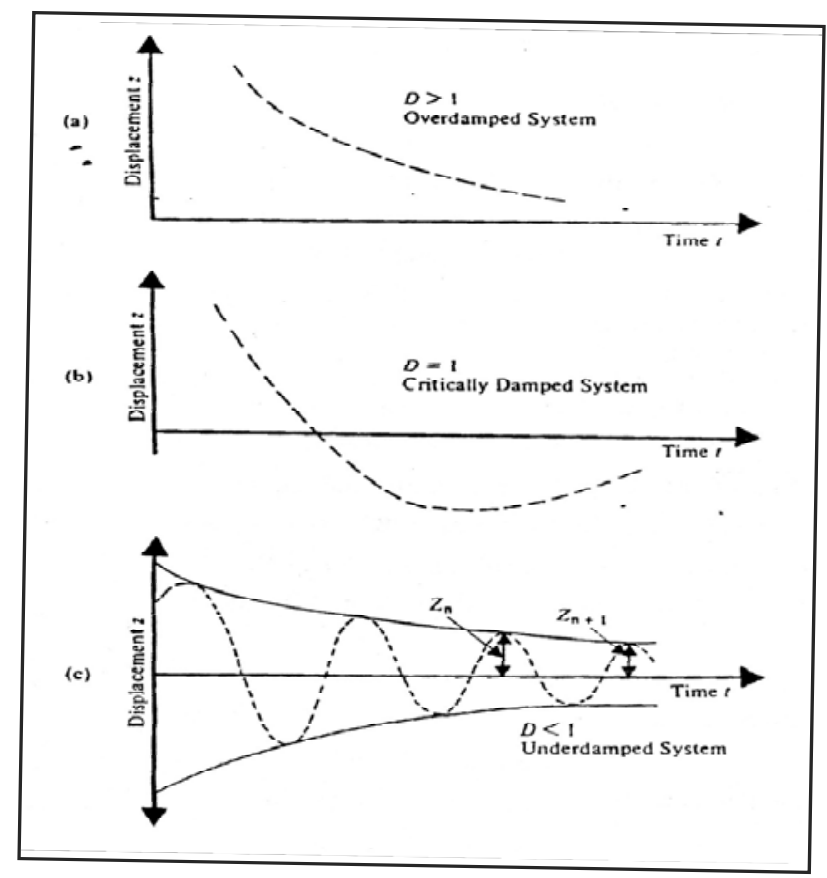

Gambar 4. Getaran Bebas dengan Redaman (a) overdamping (redaman super kritis) ; (b) critical damping (redaman kritis) dan (c) underdamping (redaman sub kritis)

Pengaruh adanya redaman adalah berkurangnya amplitudo getaran secara bertahap terhadap fungsi waktu.

\subsection{Teori Tekanan Tanah Menurut Mononobe-Okabe}

\subsubsection{Tekanan Tanah Aktif menurut Mononobe-Okabe}

Pada tahun 1776, Coulomb memperkenalkan persamaan tekanan tanah aktif $\left(P_{A}\right)$ untuk dinding penahan tanah (retaining wall) pada tanah urugan kering tak berkohesi, sebagai berikut :

$$
P_{A}=1 / 2 \gamma H^{2} K_{A}
$$

dimana :

$$
\begin{aligned}
& P_{A}=\text { gaya aktif per satu satuan panjang dinding } \\
& \gamma=\text { berat volume tanah } \\
& H=\text { tinggi retaining wall } \\
& K_{A}=\text { koefisien tekanan aktif tanah } \\
& K_{A}=\frac{\cos ^{2}(\phi-\beta)}{\cos ^{2} \beta \cos (\delta+\beta)\left[1+\left(\frac{\sin (\delta+\phi) \sin (\phi-i)}{\cos (\delta+\beta) \cos (\beta-i)}\right)^{\frac{1}{2}}\right]^{2}}
\end{aligned}
$$




$$
\text { dimana : } \begin{aligned}
\phi & =\text { sudut geser tanah } \\
\delta & =\text { sudut geser dinding } \\
\beta & =\text { kemiringan dinding terhadap bidang vertikal } \\
i & =\text { kemiringan dinding terhadap bidang horizontal }
\end{aligned}
$$

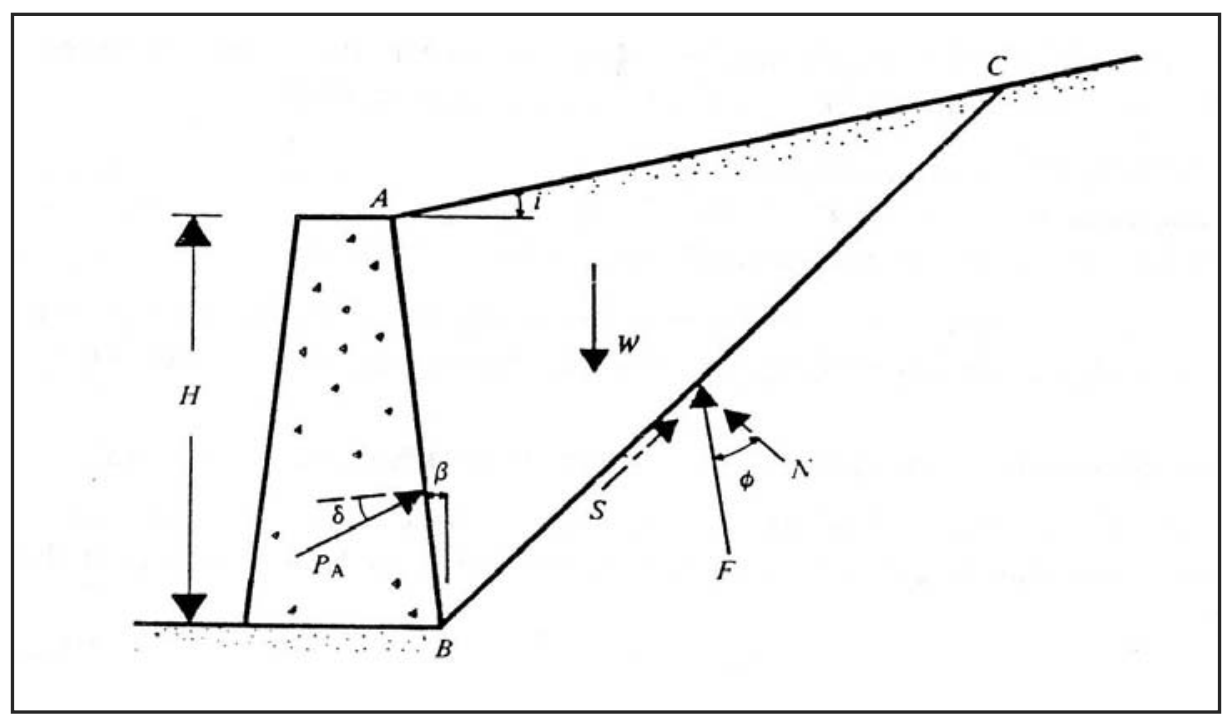

Gambar 5. Tekanan Tanah Aktif Coulomb

Persamaan tekanan tanah aktif Coulomb bisa dimodifikasi untuk menghitung koefisien percepatan vertikal dan horizontal yang disebabkan oleh gempa. Modifikasi ini secara umum dianggap sebagai Mononobe-Okabe analysis (Mononobe, 1929; Okabe, 1926).

Penyelesaian Mononobe-Okabe berdasarkan asumsi sebagai berikut :

1. Keruntuhan terjadi sepanjang garis keruntuhan $\mathrm{BC}$ pada gambar.

2. Perpindahan pada dinding cukup untuk menghasilkan tekanan aktif minimum.

3. Nilai kuat geser pada tanah tak berkohesi diperoleh dengan persamaan

$$
s=\sigma^{\prime} \tan \phi
$$

dimana $\sigma^{\prime}$ adalah tegangan efektif tanah dan $s$ adalah kekuatan geser tanah.

4. Pada saat runtuh, kuat geser terjadi sepanjang garis keruntuhan.

5. Tanah di belakang dinding penahan tanah (retaining walls) dianggap kaku.

Gaya-gaya yang diperhitungkan dalam solusi Mononobe-Okabe ditunjukkan pada Gambar 6. Garis $\mathrm{AB}$ adalah bagian belakang retaining wall dan $\mathrm{ABC}$ adalah bagian tanah yang akan mengalami keruntuhan. Gaya pada bagian yang runtuh per satu satuan panjang dinding adalah :

1. berat sendiri bagian yang runtuh $(W)$

2. gaya aktif $\left(P_{A E}\right)$

3. resultan gaya geser dan normal sepanjang bidang runtuh $F$

4. $k_{h} W$ dan $k_{v} W$, momen inersia dalam arah horizontal dan vertikal, dimana;

$$
\begin{aligned}
& k_{h}=\frac{\text { percepatan gempa dari komponen horizontal }}{g} \\
& k_{v}=\frac{\text { percepatan gempa dari komponen vertikal }}{g}
\end{aligned}
$$

dimana $g$ adalah percepatan gravitasi. 


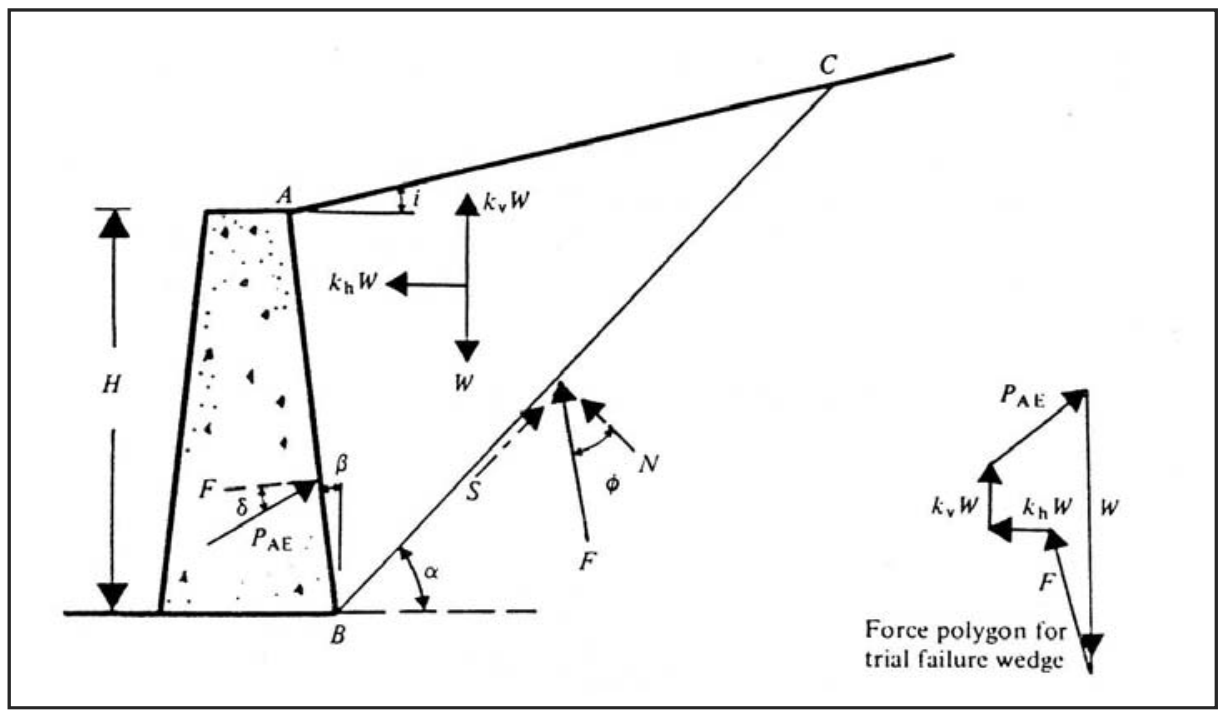

Gambar 6. Asal Mula Persamaan Mononobe-Okabe

Gaya aktif ditentukan dari analisis lapisan yang digambarkan dalam persamaan berikut :

$$
P_{A E}=1 / 2 \gamma H^{2}\left(1-k_{v}\right) K_{A E}
$$

dimana :

$K_{A E}=$ koefisien tekanan tanah aktif dengan pengaruh gempa.

$$
\begin{aligned}
K_{A E}= & \frac{\cos ^{2}(\phi-\theta-\beta)}{\cos \theta \cos ^{2} \beta \cos (\delta+\beta+\theta)\left[1+\sqrt{\frac{\sin (\delta+\phi) \sin (\phi-\theta-i)}{\cos (\delta+\beta+\theta) \cos (i-\beta)}}\right]^{2}} \\
\theta= & \tan ^{-1}\left[\frac{k_{h}}{\left(1-k_{v}\right)}\right]
\end{aligned}
$$

\subsubsection{Tekanan Tanah Pasif menurut Mononobe-Okabe}

Gaya pasif per satuan panjang dinding akibat gempa adalah sebagai berikut :

$$
P_{P E}=1 / 2 \gamma H^{2}\left(1-k_{v}\right) K_{P E}
$$

dimana :

$$
\begin{aligned}
K_{P E}= & \text { koefisien tekanan tanah pasif dengan pengaruh gempa. } \\
K_{P E}= & \frac{\sin ^{2}(\beta+\theta-\phi)}{\cos \theta \sin ^{2} \beta \sin (\delta+\beta+\theta-90)\left[1-\sqrt{\frac{\sin (\delta+\phi) \sin (\phi-\theta+\alpha)}{\cos (\delta+\beta+\theta) \cos (\alpha-\beta)}}\right]^{2}} \\
\theta= & \tan ^{-1}\left[\frac{k_{h}}{\left(1-k_{v}\right)}\right]
\end{aligned}
$$

\section{ANALISA DAN PEMBAHASAN}

Gambar di bawah ini merupakan contoh kasus dari dinding penahan tanah (retaining wall) yang akan dianalisis. 


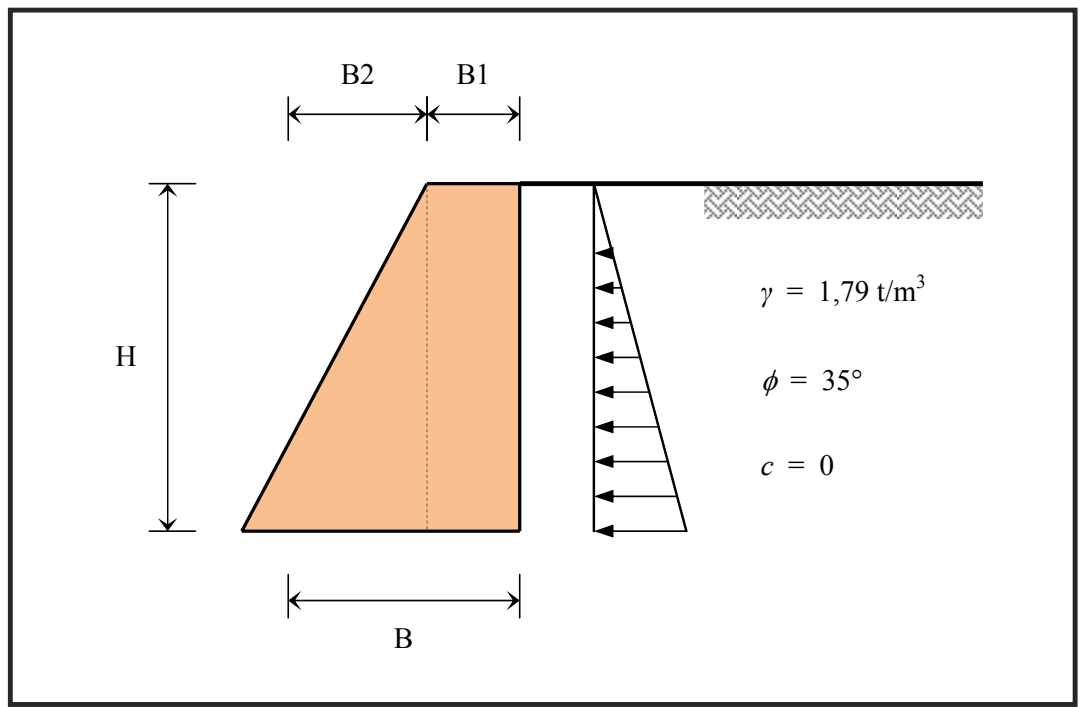

Gambar 7. Contoh Kasus

Data Tanah :

- Tanah pengisi $\quad=$ pasir lepas

- Sudut geser $(\phi) \quad=35^{\circ}$

- Berat jenis beton $\left(\gamma_{c}\right) \quad=2,40 \mathrm{t} / \mathrm{m}^{3}$

- Berat jenis tanah $\left(\gamma_{s}\right) \quad=1,79 \mathrm{t} / \mathrm{m}^{3}$

- Koef. gempa $\left(K_{h}\right) \quad=$ percepatan gempa $\left(a_{g}\right)=0,05 g$

- Percepatan gravitasi $(g)=9,81 \mathrm{~m} / \mathrm{dt}^{2}$

Dimensi Dinding Penahan Tanah :
- $B=4,00 \mathrm{~m}$
$-\mathrm{B} 1=1,50 \mathrm{~m}$
$-\mathrm{H}=9,00 \mathrm{~m}$
$-\quad B 2=2,50 \mathrm{~m}$

\section{A. Stabilitas Eksternal}

1. Perhitungan Berat dan Gaya pada Dinding Penahan Tanah

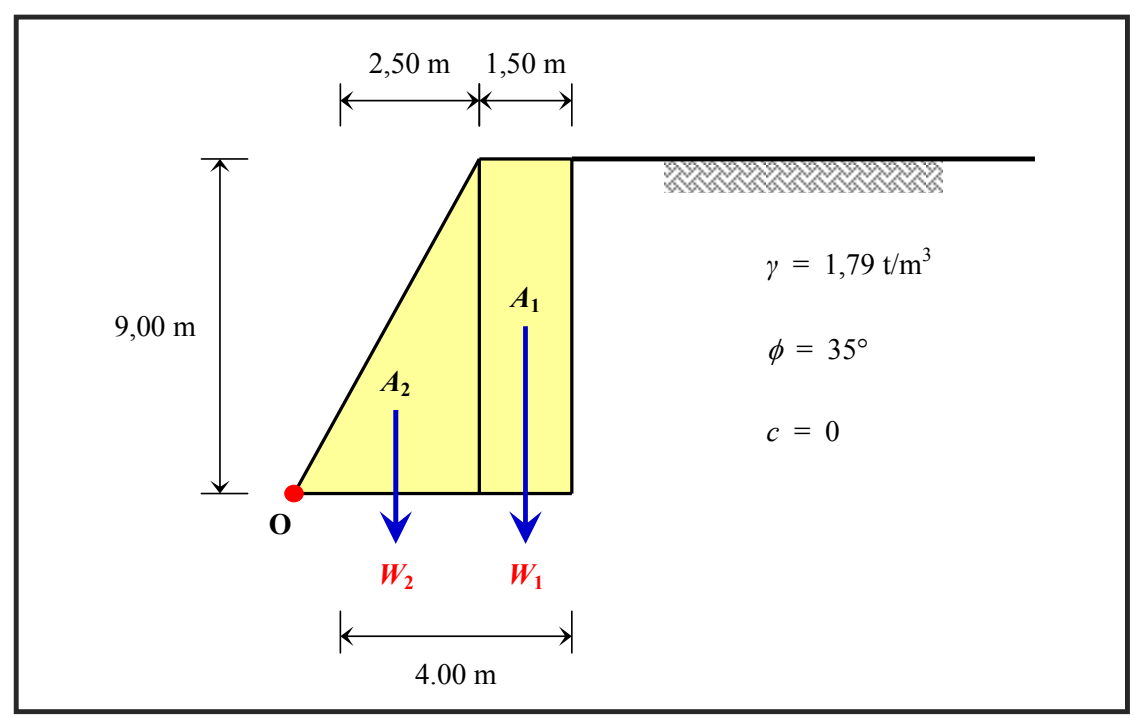


Tabel 1. Perhitungan Berat Dinding Penahan Tanah dan Momen Tahanan terhadap titik O

\begin{tabular}{|c|c|c|c|c|}
\hline No. & Uraian Perhitungan Berat Dinding & $\begin{array}{c}\text { Berat Dinding } \\
(\text { ton })\end{array}$ & $\begin{array}{c}\text { Lengan } \\
\text { Momen }(\mathrm{m})\end{array}$ & $\begin{array}{c}\text { Momen Tahanan } \\
\text { (ton.m) }\end{array}$ \\
\hline 1. & $W_{1}=2,40 \times(1,50 \times 9,0)$ & 32,40 & 3,25 & 105,30 \\
\hline 2. & $W_{2}=2,40 \times(1 / 2 \times 2,50 \times 9,0)$ & 27,00 & 1,67 & 45,00 \\
\hline & Total & $\mathbf{5 9 , 4 0}$ & & $\mathbf{1 5 0 , 3 0}$ \\
\hline
\end{tabular}

Keterangan :

$W_{i}=\gamma_{c} A_{i}, \quad$ merupakan berat dari dinding penahan tanah (retaining wall) persatuan panjang dinding, $\gamma_{c}$ adalah berat volume dinding yang terbuat dari beton $\left(\gamma_{c}=2.40 \mathrm{t} / \mathrm{m}^{3}\right)$ dan $A_{i}$ adalah luas penampang dari bagian-bagian dinding penahan tanah.

\section{Perhitungan Tekanan Tanah}

Tekanan tanah aktif di belakang dinding penahan tanah (retaining wall), dihitung berdasarkan metode Rankine, yaitu sebagai berikut :

$$
\begin{array}{lll}
K_{a}=\tan ^{2}(45-\phi / 2) & =\tan ^{2}[45-(35 / 2)] & =0,270 \\
P_{a}=1 / 2 K a \gamma H^{2} & =1 / 2(0,27)(1,79)\left(9,0^{2}\right) & =19,574 \text { ton }
\end{array}
$$

\section{Resume Beban-Beban dan Gaya-Gaya yang Bekerja pada Dinding Penahan Tanah}

Tabel 2. Resume Beban-Beban dan Gaya-Gaya yang Bekerja pada Dinding Penahan Tanah

\begin{tabular}{|c|c|c|c|c|c|}
\hline No. & Beban & Nilai Beban (ton) & Lengan Momen (m) & $\boldsymbol{M}_{\boldsymbol{O}}$ (ton.m) & $\boldsymbol{M}_{\boldsymbol{R}}$ (ton.m) \\
\hline 1. & $\boldsymbol{W}_{\mathbf{1}}$ & 32,400 & 3,250 & - & $\mathbf{1 0 5 , 3 0}$ \\
\hline 2. & $\boldsymbol{W}_{\mathbf{2}}$ & 27,000 & 1,667 & - & $\mathbf{4 5 , 0 0}$ \\
\hline 3. & $\boldsymbol{P}_{\boldsymbol{a}}$ & 19,574 & 3,000 & $\mathbf{5 8 , 7 2 2}$ & - \\
\hline
\end{tabular}

4. Faktor Keamanan untuk Dinding Penahan Tanah

a). Faktor Keamanan terhadap Guling (Overturning)

$$
\boldsymbol{S F} \text { (overturning) }=\frac{\sum M_{R}}{\sum M_{O}}=\frac{105,30}{45,00}=\mathbf{2 , 5 6}
$$

b). Faktor Keamanan terhadap Geser (Sliding)

$$
\boldsymbol{S F} \text { (sliding) } \quad=\frac{\sum V \tan \left(k_{1} \phi\right)}{P_{a}}=\frac{(59,40) \tan [(2 / 3)(35)]}{19,574}=\mathbf{1 , 3 1}
$$

c). Faktor Keamanan terhadap Daya Dukung (Bearing Capacity)

\begin{tabular}{|c|c|c|c|c|c|c|c|}
\hline \multirow{2}{*}{$\phi$} & \multicolumn{3}{|c|}{ Keruntuhan Geser Umum } & \multirow{2}{*}{$\phi$} & \multicolumn{3}{|c|}{ Keruntuhan Geser Umum } \\
\hline & $N_{c}$ & $N_{q}$ & $N_{\gamma}$ & & $N_{c}$ & $N_{q}$ & $N_{y}$ \\
\hline 0 & 5,7 & 1,0 & 0,0 & 25 & 25,1 & 12,7 & 9,7 \\
\hline 5 & 7,3 & 1,6 & 0,5 & 30 & 37,2 & 22,5 & 19,7 \\
\hline 10 & 9,6 & 2,7 & 1,2 & 35 & 57,8 & 41,4 & 42,4 \\
\hline 15 & 12,9 & 4,4 & 2,5 & 40 & 95,7 & 81,3 & 100,4 \\
\hline 20 & 17,7 & 7,4 & 5,0 & 45 & 172,3 & 173,3 & 297,5 \\
\hline
\end{tabular}

Kapasitas dukung ultimit dihitung menggunakan persamaan Terzaghi dengan asumsi bahwa dinding penahan tanah merupakan pondasi memanjang.

Tabel 3. Nilai-Nilai Faktor Kapasitas Daya Dukung Terzaghi 
Untuk $\phi=35^{\circ}$, dari Tabel 3, diperoleh :

- $N_{q}=41,40$ dan $N_{\gamma}=42,20$

- $q_{u}=q N_{q}+1 / 2 B \gamma N_{\gamma}=(0,0)(41,40)+1 / 2(4,0)(1,79)(42,20)=151,076 \mathrm{t} / \mathrm{m}^{2}$

- $q_{\max }=\frac{V}{B}+\frac{1}{12 B} \quad=\frac{59,40}{4,0}+\frac{1}{12(4,0)}=14,871 \mathrm{t} / \mathrm{m}^{2}$

- $\boldsymbol{S F}$ (bearing capacity) $=\frac{q_{u}}{q_{\max }}=\frac{151,076}{14,781}=\mathbf{1 0 , 6 1}$

\section{B. Stabilitas Dinamis}

Stabilitas dinamis dinding penahan tanah dengan sudut keruntuhan $\alpha=45+\phi / 2$, sebagai berikut :

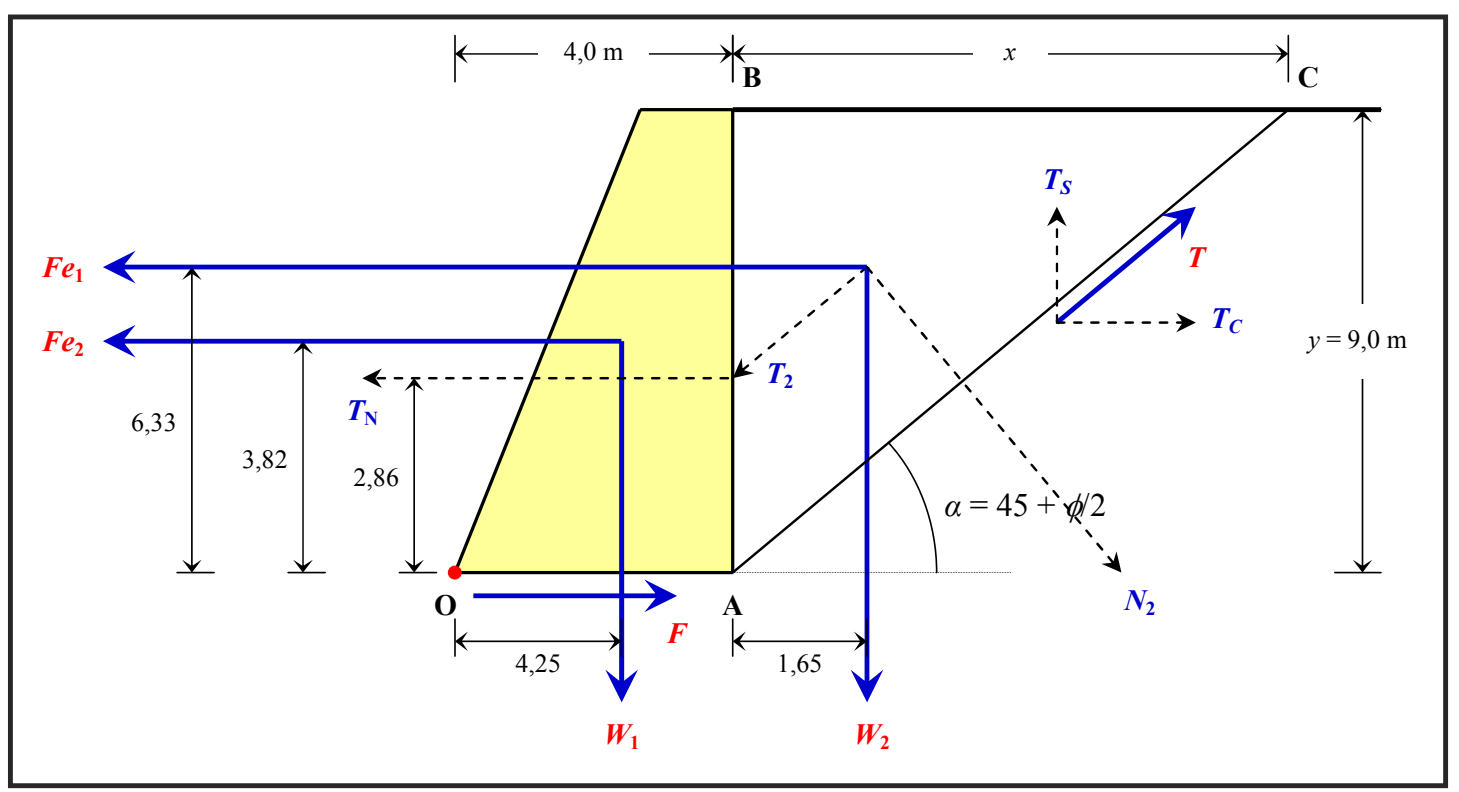

Panjang bidang runuh di belakang dinding penahan tanah :

$$
\begin{aligned}
& \text { Panjang } \mathrm{AC}=r \\
& \text { Panjang } \mathrm{AB}=y \\
& \text { Panjang } \mathrm{BC}=x \\
& \sin \alpha=\frac{y}{r} \\
& \sin (45+\phi / 2)=\frac{9}{r} \\
& r=\frac{9}{\sin (45+(\phi / 2))}=\frac{9}{\sin (45+(35 / 2))}=10,15 \mathrm{~m} \\
& x=\sqrt{r^{2}-y^{2}}=\sqrt{(10,15)^{2}-(9.0)^{2}}=4,68 \mathrm{~m}
\end{aligned}
$$

Gaya-gaya-gaya dinamis yang bekerja pada dinding penahan tanah :

$$
\begin{array}{ll}
W_{1}=\gamma 1 \times A_{1} & =59,40 \mathrm{t} / \mathrm{m} \\
W_{2}=\gamma 2 \times A_{2} & =37,70 \mathrm{t} / \mathrm{m}
\end{array}
$$




$$
\begin{aligned}
& F e_{1}=\left(W_{1} / g\right) \times a_{g}=2,970 \text { ton } \\
& \mathrm{Fe}_{2}=\left(W_{2} / g\right) \times a_{g}=1,885 \text { ton } \\
& N_{2}=W_{2} \cos \alpha=37,70(\cos 62,5)=17,41 \mathrm{t} / \mathrm{m} \\
& T_{2}=W_{2} \sin \alpha=37,70(\sin 62,5)=33,44 \mathrm{t} / \mathrm{m} \\
& T=N_{2} \tan \phi=17,4(\tan 35)=12,19 \mathrm{t} / \mathrm{m} \\
& F=W_{1} \tan \phi \quad=59,4(\tan 35) \quad=\quad 41,59 \mathrm{t} / \mathrm{m} \\
& T_{N}=T_{2} \cos \alpha=33,44(\cos 62,5)=15,44 \mathrm{t} / \mathrm{m} \\
& T_{C}=T \cos \alpha=12,19(\cos 62,5)=5,63 \mathrm{t} / \mathrm{m} \\
& T_{S}=T \sin \alpha=12,19(\sin 62,5)=10,81 \mathrm{t} / \mathrm{m}
\end{aligned}
$$

Tabel 4. Resume Beban-Beban dan Gaya-Gaya yang Bekerja pada Dinding Penahan Tanah

\begin{tabular}{|c|c|c|c|c|c|}
\hline No. & Beban & Nilai Beban (ton) & Lengan Momen $(\mathrm{m})$ & $\boldsymbol{M}_{\boldsymbol{O}}$ (ton.m) & $\boldsymbol{M}_{\boldsymbol{R}}$ (ton.m) \\
\hline 1. & $\boldsymbol{W}_{\mathbf{1}}$ & 59,4 & 4,25 & - & $\mathbf{2 5 2 , 4 5 0}$ \\
\hline 2. & $\boldsymbol{T}_{\boldsymbol{N}}$ & 15,44 & 2,86 & $\mathbf{4 4 , 1 5 8}$ & - \\
\hline 3. & $\boldsymbol{F e}_{\mathbf{1}}$ & 2,97 & 3,82 & $\mathbf{1 1 , 3 4 5}$ & - \\
\hline 4. & $\boldsymbol{F e}_{\mathbf{2}}$ & 1,885 & 6,33 & $\mathbf{1 1 , 9 3 2}$ & - \\
\hline \multicolumn{5}{|r}{} \\
\hline
\end{tabular}

Faktor keamanan untuk dinding penahan tanah :

a). Faktor Keamanan terhadap Guling (Overturning)

$$
\begin{aligned}
\boldsymbol{S F}_{\text {(overturning) }} & =\frac{\sum M_{R}}{\sum M_{O}}=\frac{W_{1}}{T_{N}+F e_{1}+F e_{2}}=\frac{252,45}{44,158+11,345+11,932}=\frac{252,45}{67,437} \\
& =\mathbf{3 , 7 4}
\end{aligned}
$$

b). Faktor Keamanan terhadap Geser (Sliding)

$$
\boldsymbol{S F}_{\text {(sliding) }}=\frac{T_{C}+F}{T_{N}+F e_{1}+F e_{2}}=\frac{5,63+41,59}{15,44+2,97+1,885}=\frac{47,22}{20,295}=\mathbf{2 , 3 3}
$$

c). Faktor Keamanan terhadap Daya Dukung (Bearing Capacity)

- Kapasitas daya dukung :

$$
\begin{aligned}
q_{\max } & =\frac{V}{B}+\frac{1}{12 B}=\frac{(59,40+37,70)}{4,0}+\frac{1}{12(4,0)}=24,296 \\
N_{q} & =41,40 \\
N_{\gamma} & =42,20 \\
q_{u} & =q N_{q}+1 / 2 B \gamma N_{\gamma}=(0)(41,40)+1 / 2(4,0)(1,79)(42,20)=151,076 \mathrm{t} / \mathrm{m}^{2}
\end{aligned}
$$

- Faktor keamanan terhadap daya dukung :

$$
\boldsymbol{S F}_{(\text {bearing capacity })}=\frac{q_{u}}{q_{\max }}=\frac{151,076}{24,296}=\mathbf{1 0 , 6 1}
$$

Tabel 5. Resume Hasil Perhitungan Angka Keamanan

\begin{tabular}{|c|l|c|c|c|c|}
\hline No. & \multicolumn{1}{|c|}{ Jenis Stabilitas } & Statis & $\begin{array}{c}\text { Mononobe - } \\
\text { Okabe }\end{array}$ & $\alpha=45+\phi / 2$ & $\alpha=\phi$ \\
\hline 1. & Overtuning (Guling) & $\mathbf{2 , 5 6}$ & $\mathbf{0 , 8 5}$ & $\mathbf{3 , 7 7}$ & $\mathbf{0 , 9 0}$ \\
\hline 2. & Sliding (Geser) & $\mathbf{1 , 3 1}$ & $\mathbf{0 , 6 1}$ & $\mathbf{2 , 3 3}$ & $\mathbf{1 , 5 9}$ \\
\hline 3. & $\begin{array}{l}\text { Bearing Capacity (Daya } \\
\text { Dukung) }\end{array}$ & $\mathbf{1 0 , 1 6}$ & $\mathbf{1 0 , 1 6}$ & $\mathbf{6 , 2 2}$ & $\mathbf{4 , 9 8}$ \\
\hline
\end{tabular}


Dari perhitungan mencari angka keamanan dinding penahan dalam kondisi statis, didapatkan angka keamanan yang besar dari batas angka keamanan yang diambil yaitu $1-2$. Masing-masing angka keamanan tersebut adalah 2,56 untuk angka keamanan guling, 1,31 untuk angka keamanan geser, dan 10,16 untuk angka keamanan terhadap daya dukung tanah dasar. Perhitungan statis ini dilakukan untuk mengetahui apakah dinding penahan tanah mampu menahan berat sendiri dan gaya aktif tanah di belakangnya.

Perhitungan dilanjutkan dengan mencari angka keamanan dinding dengan pengaruh gempa yang menggunakan metode Mononobe-Okabe. Dari perhitungan ini didapatkan angka keamanan guling dan geser dibawah batas yang diambil, tetapi angka keamanan untuk daya dukung tanah dasar berada diatas batas yang diambil. Angka keamanan untuk guling yang diperoleh adalah 0,85 dan untuk geser 0,61. Sedangkan angka keamanan untuk daya dukung tanah dasar adalah 10,16.

Setelah dilakukan analisa dengan menggunakan software, dilakukan perhitungan untuk mencari stabilitas dinamis dengan dua sudut keruntuhan yaitu $\alpha=45+\phi / 2$ dan $\alpha=\phi$.

Dari perhitungan dengan sudut keruntuhan $\alpha=45+\phi / 2$ didapat angka keamanan untuk guling 3,77; sedangkan angka keamanan untuk geser dan daya dukung tanah dasar masing-masing 2,33 dan 6,22 . Kemudian dari perhitungan dengan sudut keruntuhan $\alpha=\phi$, angka keamanan yang didapat untuk guling adalah 0,9 ; sedangkan angka keamanan untuk geser dan daya dukung tanah dasar adalah 1,59 dan 4,98 .

Dari hasil keluaran running program, terjadi perpindahan horizontal arah $\mathrm{X}\left(U_{x}\right)$ sejauh 475,08 $\times$ $10^{-3} \mathrm{~m}$ dengan besar penambahan perpindahan $\left(d U_{x}\right)$ sebesar $28,56 \times 10^{-6} \mathrm{~m}$. Untuk kecepatan maksimum horizontal arah $\mathrm{X}$ adalah $62,83 \times 10^{-3} \mathrm{~m} / \mathrm{s}$ dan percepatan maksimum horizontal arah $\mathrm{X}$ adalah $212,01 \times 10^{-3} \mathrm{~m} / \mathrm{s}^{2}$.

\section{KESIMPULAN}

Bedasarkan hasil analisis yang telah dilakukan, dapat diambil kesimpulan sebagai berikut :

1. Dari hasil perhitungan stabilitas statis didapatkan hasil bahwa struktur dinding penahan tanah akan stabil terhadap guling, geser dan keruntuhan.

2. Dari hasil perhitungan stabilitas dinamis dengan sudut keruntuhan $\alpha=45+\phi / 2$ didapatkan hasil bahwa struktur dinding penahan tanah akan stabil terhadap guling, geser dan keruntuhan. Sedangkan dari hasil perhitungan dengan sudut keruntuhan $\alpha=\phi$ dinding penahan taah akan mengalami guling.

3. Dari hasil perhitungan stabilitas dengan menambahkan pengaruh beban gempa, struktur dinding penahan tanah akan mengalami guling dan geser.

\section{DAFTAR PUSTAKA}

Das, Braja M., (1995), "Mekanika Tanah", Jilid 2, Erlangga, Jakarta.

Das, Braja M., (1984), "Fundamentals of Soil Dynamics", Elsevier Science Publishing Co. Inc., New York. 
Analisa Stabilitas Dinding Penahan Tanah (Retaining Wall) Akibat Beban Dinamis dengan Simulasi Numerik

54 J URNAL REKAYASA SIPIL 